\title{
Importance of maximum snow accumulation for summer low flows in humid catchments
}

\author{
Michal Jenicek $^{1}$, Jan Seibert ${ }^{2,3}$, Massimiliano Zappa ${ }^{4}$, Maria Staudinger ${ }^{2}$, and Tobias Jonas ${ }^{5}$ \\ ${ }^{1}$ Charles University in Prague, Faculty of Science, Department of Physical Geography and Geoecology, \\ Prague, Czech Republic \\ ${ }^{2}$ University of Zurich, Department of Geography, Zurich, Switzerland \\ ${ }^{3}$ Uppsala University, Department of Earth Sciences, Uppsala, Sweden \\ ${ }^{4}$ Swiss Federal Institute for Forest, Snow and Landscape Research WSL, Birmensdorf, Switzerland \\ ${ }^{5}$ WSL Institute for Snow and Avalanche Research SLF, Davos, Switzerland
}

Correspondence to: Michal Jenicek (michal.jenicek@natur.cuni.cz)

Received: 29 June 2015 - Published in Hydrol. Earth Syst. Sci. Discuss.: 24 July 2015

Revised: 30 January 2016 - Accepted: 9 February 2016 - Published: 23 February 2016

\begin{abstract}
Winter snow accumulation obviously has an effect on the following catchment runoff. The question is, however, how long this effect lasts and how important it is compared to rainfall inputs. Here we investigate the relative importance of snow accumulation on one critical aspect of runoff, namely the summer low flow. This is especially relevant as the expected increase of air temperature might result in decreased snow storage. A decrease of snow will affect soil and groundwater storages during spring and might cause low streamflow values in the subsequent warm season. To understand these potential climate change impacts, a better evaluation of the effects of inter-annual variations in snow accumulation on summer low flow under current conditions is central. The objective in this study was (1) to quantify how long snowmelt affects runoff after melt-out and (2) to estimate the sensitivity of catchments with different elevation ranges to changes in snowpack. To find suitable predictors of summer low flow we used long time series from 14 Alpine and pre-Alpine catchments in Switzerland and computed different variables quantifying winter and spring snow conditions. In general, the results indicated that maximum winter snow water equivalent (SWE) influenced summer low flow, but could expectedly only partly explain the observed inter-annual variations. On average, a decrease of maximum SWE by $10 \%$ caused a decrease of minimum discharge in July by 6-9\% in catchments higher than $2000 \mathrm{~m}$ a.s.1. This effect was smaller in middle- and lower-elevation catchments with a decrease of minimum discharge by $2-5 \%$ per $10 \%$ decrease of maxi-
\end{abstract}

mum SWE. For higher- and middle-elevation catchments and years with below-average SWE maximum, the minimum discharge in July decreased to 70-90\% of its normal level. Additionally, a reduction in SWE resulted in earlier low-flow occurrence in some cases. One other important factor was the precipitation between maximum SWE and summer low flow. When only dry preceding conditions in this period were considered, the importance of maximum SWE as a predictor of low flows increased. We assessed the sensitivity of individual catchments to the change of maximum SWE using the non-parametric Theil-Sen approach as well as an elasticity index. Both sensitivity indicators increased with increasing mean catchment elevation, indicating a higher sensitivity of summer low flow to snow accumulation in Alpine catchments compared to lower-elevation pre-Alpine catchments.

\section{Introduction}

The shift from snowfall to rain is one of the most important effects of predicted climate change on the hydrological cycle (Laghari et al., 2012; Berghuijs et al., 2014; Zhang et al., 2015). This shift results in a decrease of the fraction of solid precipitation (snow/total precipitation, known as $S / P$ ) and thus in a decrease of snow accumulation especially in midelevation mountain ranges (Knowles et al., 2006; Pellicciotti et al., 2010; Speich et al., 2015). The decrease of $S / P$ will affect groundwater recharge during spring and as a conse- 
quence also low streamflow values in the subsequent summer period (Bavay et al., 2009; Godsey et al., 2014).

For the western United States the decrease of $S / P$ at low and middle elevations during the last decades could be explained mainly by an increase of air temperature during wet days in winter (cold season) (Knowles et al., 2006). The simultaneous change in winter precipitation amount for that region explained only a minor part of the decrease in $S / P$ (Feng and $\mathrm{Hu}, 2007$ ). The largest decrease in $S / P$ was found in March for the whole study region and additionally in January near the West Coast with generally higher air temperature during winter (Knowles et al., 2006). This led to the conclusion that an air temperature increase from December to March had the largest impact on snow accumulation, while warming from April to June rather affected snowmelt onset, dynamics and melt-out (point in time at which all snowmelt out of the catchment) (Knowles et al., 2006; Feng and Hu, 2007).

Berghuijs et al. (2014) showed that a higher fraction of precipitation fallen as snow is associated with higher long-term mean streamflow in comparison to catchments with lower snowfall fraction. Higher air temperatures during spring affect the onset of snowmelt in streamflow shifting it towards earlier spring (Barnett et al., 2005; Godsey et al., 2014; Langhammer et al., 2015; Ledvinka, 2015). These changes lead to a higher fraction of annual flow occurring earlier in the water year as evident from many studies across the western United States (Cayan et al., 2001; Stewart et al., 2005; Day, 2009). However, snowmelt and consequent spring streamflow are affected by a wide range of factors, such as topography, vegetation and connected radiation as well as shading effects which might overlay the effect of increasing air temperature (Kliment et al., 2011; Kutlakova and Jenicek, 2012; Pomeroy et al., 2012; Kucerova and Jenicek, 2014). Earlier onset of snowmelt could, for instance, be slowed down by less shortwave radiation due to lower sun inclination in early spring (Lundquist and Flint, 2006).

Speich et al. (2015) demonstrated the sensitivity of catchments in the Swiss Alps to a reduction of snow contribution to total runoff by applying bivariate-mapping techniques. The combination of total runoff and snowmelt appeared to be more sensitive to predicted future changes of air temperature and precipitation than the combination of precipitation and potential evapotranspiration (Speich et al., 2015). Additionally, the elevation band between 1000 and $2500 \mathrm{~m}$ a.s.1. was found to be relatively more sensitive to future temperature and precipitation scenarios than lower-elevation bands. Further, Zappa and Kan (2007) demonstrated that the presence of above-average snow resources contributed to mitigating the effects of the 2003 summer drought in some highelevation areas within the Swiss Alps.

Snow conditions in winter can affect low flows during the subsequent summer, especially in areas with large differences in winter and summer precipitation. The total amount of snow precipitation in winter affects groundwater recharge and hence also runoff during dry summer periods (Earman et al., 2006; Beaulieu et al., 2012; Van Loon et al., 2015). While meteorological drivers and overall catchment storage both affect the drought duration during summer, seasonal storage in snow and glaciers affect the drought deficit (Van Loon and Laaha, 2015). However, snow cannot solely explain the sensitivity to drought, although higher-elevation catchments in the Swiss Alps were found to be less sensitive to drought origin (Staudinger et al., 2015). Additionally, some modelling experiments suggested larger groundwater storages in higher-elevation Swiss catchments which may additionally explain the lower sensitivity of higher-elevation catchments to low flows (Staudinger and Seibert, 2014).

Based on historical records from selected Sierra Nevada catchments in the western United States, every $10 \%$ decrease in snow water equivalent maximum in spring leads to a decrease of $9-22 \%$ in minimum runoff during summer months and the runoff minimum occurs about 3-7 days earlier (Godsey et al., 2014). Higher-elevation catchments showed a longer memory to the previous season's climate variability than lower-elevation catchments (Cayan et al., 1993), and some catchments in the Sierra Nevada mountains were affected by the snowpack of the preceding year during the subsequent summer runoff (Godsey et al., 2014).

The above-mentioned studies show that the influence of snow amount on early spring discharge is widely studied and known. However, we still lack a quantitative assessment of the sensitivity of summer low flows on snow conditions from the preceding winter. In this study we want (1) to quantify how long snowmelt affects runoff after melt-out and (2) to estimate the sensitivity of the catchments to changes in snowpack. We benefit from a recently generated snow water equivalent (SWE) data set which allowed for an indepth analysis of snowpack changes and detection of meltout dates. Our study adds to earlier studies, by focusing on the combined effect of snow and liquid precipitation during the warm period and its varying importance for individual catchments. Exploring this combined effect is particularly important in humid regions where annual precipitation is approximately equally distributed over the year, while most studies were performed in climates with more seasonal precipitation and/or smaller precipitation amounts overall (such as in the western United States). Furthermore, we set the sensitivities of low flows to varying snow conditions in the context of simple catchment properties which offers a way to indicate regions that might become more vulnerable to droughts in the future.

\section{Material and methods}

\subsection{Study area}

We selected 14 Alpine and pre-Alpine catchments in Switzerland with a catchment area ranging from 0.93 to 
Table 1. Study catchments and selected characteristics ( $S / P$ refers to the ratio of snowfall to total precipitation).

\begin{tabular}{|c|c|c|c|c|c|c|c|c|c|c|}
\hline $\begin{array}{l}\text { Catchment } \\
\text { (gauging station) }\end{array}$ & $\begin{array}{l}\text { Area } \\
\left(\mathrm{km}^{2}\right)\end{array}$ & $\begin{array}{r}\text { Mean } \\
\text { elevation } \\
\text { (m a.s.1.) }\end{array}$ & $\begin{array}{r}\text { Elevation } \\
\text { range } \\
\text { (m a.s.1.) }\end{array}$ & $\begin{array}{r}\text { Mean } \\
\text { slope } \\
\left({ }^{\circ}\right)\end{array}$ & $\begin{array}{c}\text { Drainage } \\
\text { density } \\
\left(\mathrm{km} \mathrm{km}^{-2}\right)\end{array}$ & $\begin{array}{r}\text { Mean } \\
\mathrm{SWE}_{\max } \\
(\mathrm{mm})\end{array}$ & $\begin{array}{l}\text { Mean } \\
\text { melt-out }\end{array}$ & $\begin{array}{c}S / P \\
{[-]}\end{array}$ & $\begin{array}{l}\text { Winter } \\
\text { precipitation } \\
(\mathrm{mm})\end{array}$ & $\begin{array}{c}\text { Data } \\
\text { from } \\
\text { (to } \\
2012 \text { ) }\end{array}$ \\
\hline Dischmabach (Davos) & 42.9 & 2368 & $1667-3138$ & 22.9 & 4.44 & 484 & 26 Jun & 0.97 & 365 & 1971 \\
\hline Ova Da Cluozza (Zernez) & 27.0 & 2361 & $1507-3160$ & 26.8 & 3.75 & 339 & 22 Jun & 0.98 & 349 & 1971 \\
\hline Ova Dal Fuorn (Zernez) & 55.3 & 2328 & $1706-3156$ & 18.9 & 3.59 & 339 & 15 Jun & 0.97 & 338 & 1971 \\
\hline Hinterrhein (Fürstenau) & 1577 & 2113 & 649-3406 & 21.9 & 3.64 & 333 & $1 \mathrm{Jul}$ & 0.91 & 403 & 1974 \\
\hline Vorderrhein (Ilanz) & 774 & 2023 & $691-3605$ & 23.0 & 3.69 & 391 & $27 \mathrm{Jul}$ & 0.88 & 627 & 1971 \\
\hline Riale di Calneggia (Cavergno) & 23.9 & 1986 & $883-2911$ & 29.1 & 3.87 & 423 & 15 Jun & 0.88 & 790 & 1971 \\
\hline Allenbach (Adelboden) & 28.8 & 1851 & $1296-2753$ & 19.7 & 3.94 & 351 & 17 Jun & 0.78 & 720 & 1971 \\
\hline Simme (Oberwil) & 344 & 1632 & $776-3242$ & 18.1 & 3.54 & 530 & $16 \mathrm{Jul}$ & 0.74 & 729 & 1971 \\
\hline Grande Eau (Aigle) & 132 & 1557 & $417-3204$ & 21.1 & 3.50 & 249 & $28 \mathrm{Jun}$ & 0.71 & 789 & 1971 \\
\hline Lümpenenbach & 0.93 & 1318 & $1100-1515$ & 15.1 & 3.11 & 207 & 10 May & 0.59 & 883 & 1974 \\
\hline Emme (Eggiwil) & 124 & 1275 & $581-2220$ & 14.2 & 3.44 & 185 & 17 May & 0.59 & 680 & 1975 \\
\hline Sitter (Appenzell) & 74.4 & 1247 & $769-2501$ & 17.8 & 3.56 & 193 & 25 May & 0.62 & 787 & 1971 \\
\hline Sense (Thörishaus) & 351 & 1068 & $551-2181$ & 9.9 & 3.14 & 94 & 8 May & 0.39 & 588 & 1971 \\
\hline Gürbe (Belp) & 116 & 845 & $518-2169$ & 8.7 & 3.52 & 51 & $28 \mathrm{Apr}$ & 0.41 & 551 & 1971 \\
\hline
\end{tabular}

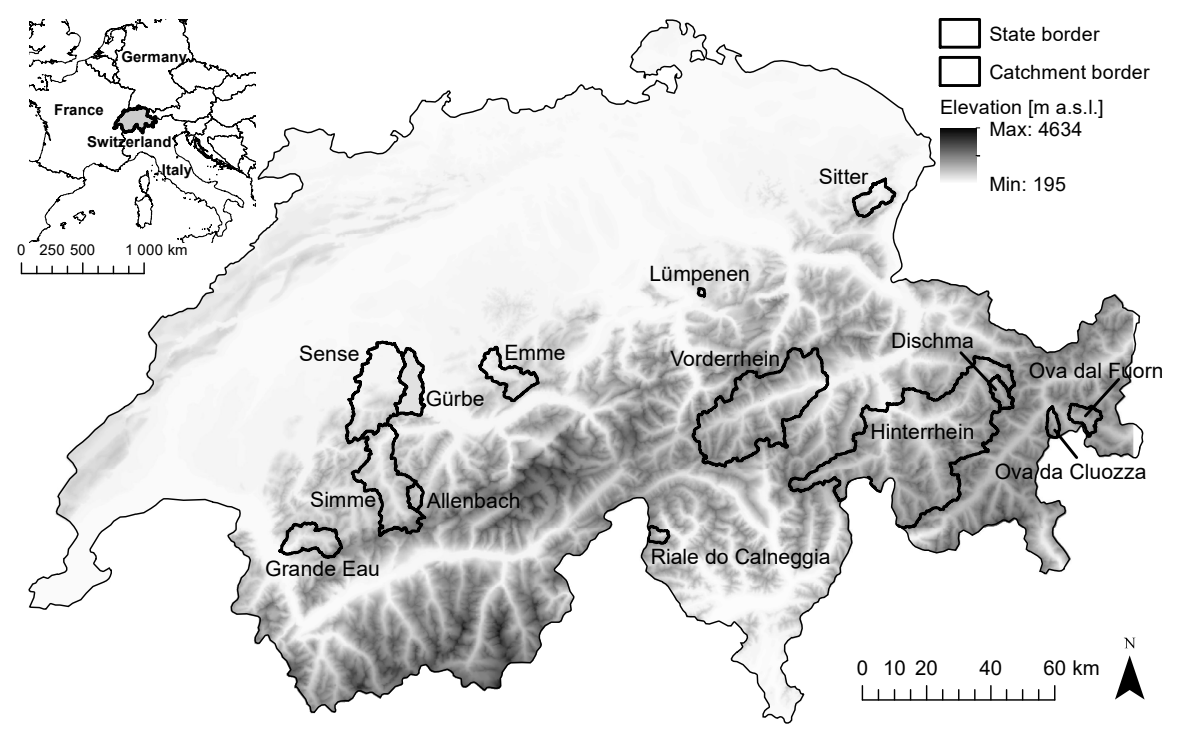

Figure 1. Location of the study catchments in Switzerland.

$1577 \mathrm{~km}^{2}$ (Fig. 1 and Table 1). Catchments as close as possible to natural conditions were selected, i.e. streamflow is near-natural and no major human influences such as dams or water transfer are present. Further, in the studied catchments there is zero or only a very small area covered by glaciers (0-2\%, except up to $4 \%$ for Vorderrhein and Simme).

\subsection{Data}

Daily gridded precipitation and air temperature data ( 2 by $2 \mathrm{~km}^{2}$ resolution) were obtained from the Swiss Federal Office of Meteorology and Climatology (MeteoSwiss; Frei and Schär, 1998; Frei, 2014) and averaged over the catchment area for use in the analyses. Daily snow water equivalent (SWE) data were also available as a gridded data set with a 1 by $1 \mathrm{~km}^{2}$ resolution. The SWE was calculated based on daily snow depth observations and a snow density model (Jonas et al., 2009) using interpolation and post-processing procedures first presented in Jörg-Hess et al. (2014). In a first step, available station data were mapped to a grid using de-trended distance weighting procedures that were specifically adapted to interpolate SWE data. To further account for changes in the number of available snow stations, the gridded data set was homogenized using the quantile mapping method. Quantile mapping is a statistical calibration method that allows a set of maps to be improved based on fewer stations, by accounting for persistent spatial patterns in maps that are based on a larger number of stations. This procedure resulted in a homogenized data set that covers the period 
Table 2. Predictor and response variables used in analyses.

\begin{tabular}{ll}
\hline Predictor variables & Response variables \\
\hline $\begin{array}{l}\text { Maximum of SWE during winter before melting } \\
\text { (catchment mean) }\end{array}$ & Minimum of 7-day moving average of discharge \\
$\begin{array}{l}\text { Maximum of SWE during winter before melting } \\
\text { (SWE mean calculated from higher situated 50\% of }\end{array}$ & Day of year (DOY) with 7-day minimum of discharge \\
catchment area) & Number of days below specified runoff threshold \\
Melt-out date (Snow-free date) & $(25 \%$ quantile of runoff from May to October used) \\
Sum of winter precipitation (November-April) & \\
$\begin{array}{l}\text { Rate of snowfall vs. total winter precipitation }(S / P) \\
\text { Sum of positive SWE changes from November to April }\end{array}$ & \\
Sum of positive air temperatures from November to April & \\
Current precipitation index $C_{\text {PI }}$ (Smakhtin and Masse, 2000) & \\
Day of year (DOY) with maximum SWE & \\
\hline
\end{tabular}

1971-2012. This same data set has already been adopted to update initial conditions of a hydrological model used for ensemble monthly predictions of SWE and runoff (Jörg-Hess et al., 2015). Further details on the methodology used to process the SWE data are available in Jörg-Hess et al. (2014), which further assessed the accuracy of the homogenized maps. Additionally, Jörg-Hess et al. (2014) used these SWE data to assess the influence of snow conditions on summer low flows for a large Swiss catchment with possible use for minimum spring and summer runoff forecast based on SWE as the only predictor.

Daily values of actual evapotranspiration (ET) were calculated using a radiation-based approach included in the PREVAH model (Gurtz et al., 1999; Viviroli et al., 2009). The PREVAH model uses observed global radiation at a daily temporal resolution as input to the Penman-Monteith equation to compute potential evapotranspiration (PET). Actual evapotranspiration is then computed by reducing PET as a function of soil water deficit. This data set was previously used and evaluated e.g. in Speich et al. (2015). The ET data were available for the period 1980-2009.

Daily discharge data were obtained from the Swiss Federal Office for the Environment (BAFU). Data from 1971 to 2012 were used in all analyses except a few shorter time series, as specified in Table 1.

\subsection{Statistical analysis and assessment}

We selected different predictors related to winter and spring meteorological conditions and water storage conditions in the catchments (Table 2).

These predictors were tested to explain the variability of three variables describing low-flow conditions: (i) minimum 7-day moving average of daily discharge was calculated based on BAFU data; different sizes of the moving window (3, 7 and 15 days) were tested without significant influence on the results; (ii) the day of year (DOY) of 7-day min- imum of discharge was calculated from June to September to exclude low flows before snowmelt or after the onset of new winter snow accumulation; (iii) number of days below a specified discharge threshold (25\% quantile of discharge from May to October).

We used nine variables as predictors of future summer low flows (Table 2). The advantage of this choice of predictors is that only SWE, precipitation, air temperature and runoff data are needed for their calculation. These data are available for many regions which allows to test our methods also elsewhere with possible transfer to ungauged catchments.

Late winter conditions were represented by the maximum SWE before snowmelt onset calculated using the SWE data from February to May. We used both the maximum SWE calculated as a catchment mean and the maximum SWE calculated from the highest $50 \%$ of the catchment area, assuming that snowpack at higher elevations melts later and could be more important for summer discharges. The melt-out date was calculated from SWE data for each catchment and year. The melt-out date was defined as the first occurrence of snow free conditions (snow cover fraction less than 10\%) after the day of maximum SWE. The sum of positive SWE changes (sum of new snow) and the sum of positive air temperatures were used as well. Both variables were calculated as a sum from 1 November to 30 April.

While the variables related to snow describe the state of the individual catchment before snowmelt, total winter precipitation calculated from 1 November to 30 April describes the available water amount from winter precipitation. Additionally, we calculated the fraction of snowfall to total winter precipitation $(S / P)$. Since information on whether precipitation occurred as rain or snow was not available, we used a threshold air temperature $\left(1.1^{\circ} \mathrm{C}\right)$ to determine the phase of precipitation. The threshold temperature near $1^{\circ} \mathrm{C}$ was used by several authors (Dai, 2008; Feiccabrino and Lundberg, 2008) who used data from stations where the information about phase of precipitation were available. Additionally, we 
tested different threshold temperatures, and found no sensitivity of our results on an exact value.

The DOY with maximum SWE was used to show the dependence of low flows on this variable. In this way, we could investigate whether low flows occur later in the year and whether low flows are higher with later occurrence of maximum SWE.

A current precipitation index $C_{\mathrm{PI}}$ (Smakhtin and Masse, 2000) was used to describe the influence of preceding liquid precipitation on low flows. $C_{\text {PI }}$ was calculated for each month from June to September for the day when 7-day minimum discharge occurred:

$C_{\mathrm{PI}(t)}=C_{\mathrm{PI}(t-1)} K+P_{t}$,

where $C_{\mathrm{PI}(t)}[\mathrm{mm}]$ is $C_{\mathrm{PI}}$ for day $t, P[\mathrm{~mm}]$ is the catchment precipitation for day $t$ and $K[-]$ is the daily recession coefficient, which usually varies from 0.85 to 0.98 (Smakhtin and Masse, 2000). We used a $K$ value of 0.93 in this study. The statistical model used in our study is not sensitive to the exact value of $K$.

The sums of actual evapotranspiration and precipitation from 1 June to 30 September and the maximum SWE were used to assess the inter-annual variability of these variables.

All parameters were calculated assuming a complete data series and additionally considering only years with belowaverage spring and summer precipitation. By doing this the effect of spring and summer liquid precipitation on low flows could be separated and thus the effect of snow could be highlighted.

To assess the relations between predictors and response variables we used the Spearman rank correlation coefficient and the bivariate linear regression. Most of the predictors and response variables were expressed as a percentage difference from the mean value, which enabled a comparison between individual catchments. The linear regression was computed from log-transformed variables. Prediction intervals of linear regression were used, which allowed the future observation of the response variable to be estimated. The R software was used for all calculations in this study (R Core Team, 2015).

The slope of regression calculated using the nonparametric Theil-Sen method was used to evaluate our statistical models. The Theil-Sen slope is a median of slopes calculated for each pair of observations (Birsan et al., 2005; Pellicciotti et al., 2010). The higher the value, the steeper the slope of regression and thus the more sensitive is the dependent variable (e.g. minimum discharge) to the change of the independent variable (e.g. maximum SWE). The Theil-Sen linear regression model is suitable for non-normally distributed data with outliers.

Similar to the slope of regression, the elasticity index (Eq. 2) was used to describe how sensitive the minimum discharge is to the change of SWE. The climate elasticity is often used to describe sensitivity of streamflow to the change of climate variables (Andréassian et al., 2015). A similar concept was used in this study to describe what percentage change of minimum discharge is caused by a defined percentage change of maximum SWE by the elasticity, $E$, which was computed by dividing the relative change in minimum discharge $\left(d Q_{\text {rel }}\right)$ by the relative change in maximum SWE, $d S_{\text {rel }}$ :

$E=d Q_{\text {rel }} / d S_{\text {rel }}$.

As the relationship between maximum SWE and minimum discharge is usually not linear, the elasticity index changes for different SWE conditions. The elasticity index was calculated from the $50 \%$ probability of prediction derived from the individual linear models.

The relative influence of snow and liquid precipitation during the warm season on low flows was analysed calculating scores for both maximum SWE and $C_{\mathrm{PI}}$ :

$$
\begin{aligned}
& S_{\text {score }}=\sum_{i=1}^{n}\left(S_{i} \times Q_{\min _{i}} / 100\right) / n \\
& C_{\mathrm{PI}_{\text {score }}}=\sum_{i=1}^{n}\left(C_{\mathrm{PI}(i)} \times Q_{\text {min }_{i}} / 100\right) / n,
\end{aligned}
$$

where $S_{i}$ is maximum SWE in year $i, Q_{\min _{i}}$ is the 7-day minimum discharge in a specific month of year $i$ and $C_{\mathrm{PI}(i)}$ is the current precipitation index on the day when $Q_{\min _{i}}$ occurs. All input values are expressed as a percentage difference from the mean (e.g. a $100 \%$ SWE represents the average maximum SWE in a catchment). The higher the score, the stronger the respective effect on low flows.

All analyses were done separately for each catchment and almost all for the period May to September to highlight the changing importance of snow contribution to low flows in different catchments and time. Analyses of the combined effect of snow and liquid precipitation were made only for the period from June to September, because liquid precipitation (expressed as $C_{\mathrm{PI}}$ ) was not calculated for May. In May there is still snow in some catchments and including it in $C_{\mathrm{PI}}$ would complicate the interpretation of the results.

\section{Results}

\subsection{Correlation of selected predictors and response variables}

Spearman rank correlation coefficients between predictors and response variables were calculated separately for three elevation classes (highest-elevation catchments: above $2000 \mathrm{~m}$ a.s.l.; middle-elevation catchments: 1300 $2000 \mathrm{~m}$ a.s.l.; low-elevation catchments: $850-1300 \mathrm{~m}$ a.s.1.) (Fig. 2). Using these three elevation classes showed changing correlations for catchments in different elevation and thus different influence of snow storage on runoff. Spearman rank correlation coefficients were displayed as heat maps together with dendrograms showing clusters (based on hierarchical 

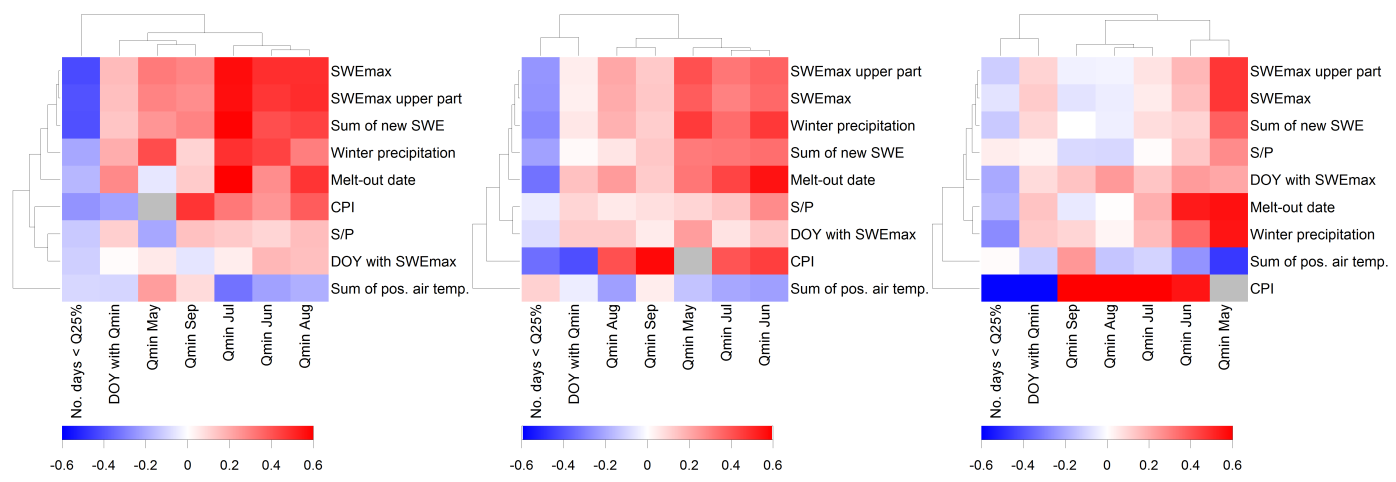

Figure 2. Heat maps showing Spearman rank correlation coefficients for all predictors (rows) and response variables (columns) separately for three elevation groups. Left panel: catchments with mean elevation higher than $2000 \mathrm{~m}$ a.s.1.; middle panel: catchments with mean elevation between 1300 and $2000 \mathrm{~m}$ a.s.l.; right panel: catchments with mean elevation between 850 and $1300 \mathrm{~m}$ a.s.1. Hierarchical cluster analysis and Euclidean distance were used to show similarity of individual predictors and response variables. Grey colour used for NA values.

cluster analysis) of similar predictors and response variables (Fig. 2).

The maximum SWE (both averaged per catchment and in upper $50 \%$ of the catchment area) was in most cases the best predictor for higher-elevation catchments during summer (July and later). Additionally, maximum SWE and the sum of new SWE were better predictors than winter precipitation in snow-dominated catchments to predict the number of days with low discharge (number of days with runoff below $Q_{25} \%$ ). In contrast, winter precipitation was a better predictor than maximum SWE for lower-elevation catchments (June to September) and for middle-elevation catchments during spring (May, June). Furthermore, the melt-out date explained a relatively high portion of the inter-annual variability during springtime for the lower-elevation catchments $(\sim 60 \%)$.

Minimum discharge and $S / P$ were surprisingly weak but significantly correlated $(p<0.05)$ from June to July (Fig. 2$)$. Less prediction ability at both higher and lower elevations could be explained by a general reduced importance of snow in lower-elevation catchments and high snowfall fraction $(>80 \%)$ in higher-elevation catchments with a consequent smaller variability of snowfall fraction in higher- than in lower-elevation catchments.

The role of spring and summer liquid precipitation (expressed as $C_{\mathrm{PI}}$ ) changed both for elevation classes and in different months showing a decreasing importance of preceding precipitation in the warm period from lower elevations to higher elevations and an increasing importance from June to September (Fig. 2). The correlation between predictors and the DOY with minimum discharge changed for three elevation classes showing decreasing correlations with SWErelated predictors and increasing correlations with preceding liquid precipitation $\left(C_{\mathrm{PI}}\right)$ from higher to lower elevations.

Despite the significance of the correlations, their values are not high, which indicates that low flows are influenced by more than a single variable (maximum explained inter- annual variability in the group was $60 \%$ ). Additionally, some of the predictors are not mutually independent (see dendrograms in Fig. 2). Since our focus was primarily on middleand high-elevation catchments as well as on summer months, maximum SWE seems to be the best predictor, although differences are not large.

\subsection{Influence of maximum SWE on low flows}

We used maximum SWE as variable to predict 7-day minimum discharge (Fig. 3). Snow influence decreased with monthly progression as shown for selected catchments representing high-, middle- and low-elevation ranges. For the three elevation ranges maximum SWE differed not only in the overall amount but also in its inter-annual variability (Fig. 3).

The relationships between the 7-day minimum discharge and maximum SWE (Fig. 3) are characterized by a large variability. This indicates that only a certain portion of lowflow variability can be explained using maximum SWE. Coefficients of determination $\left(R^{2}\right)$ were not higher than 0.65 for high-elevation catchments during late spring and early summer. In general, the ability of maximum SWE to explain minimum discharges decreased from June to September and from higher to lower elevations.

The relationship between predictor and response variable were in more detail described by the Theil-Sen slope of the regression and by the elasticity index (Figs. 4-6). The TheilSen slope and elasticity describe the sensitivity of low flows to both decrease and increase of maximum SWE.

The elasticity index for high- (mean elevation higher than $2000 \mathrm{~m}$ a.s.l.), middle- (mean elevation between 1300 and $2000 \mathrm{~m}$ a.s.l.) and low- (mean elevation between 850 and $1300 \mathrm{~m}$ a.s.l.) elevation catchments (Fig. 4) decreased progressing from June to September. The elasticity index for high-elevation catchments was for each month higher than the elasticity index for middle- and low-elevation catchments 

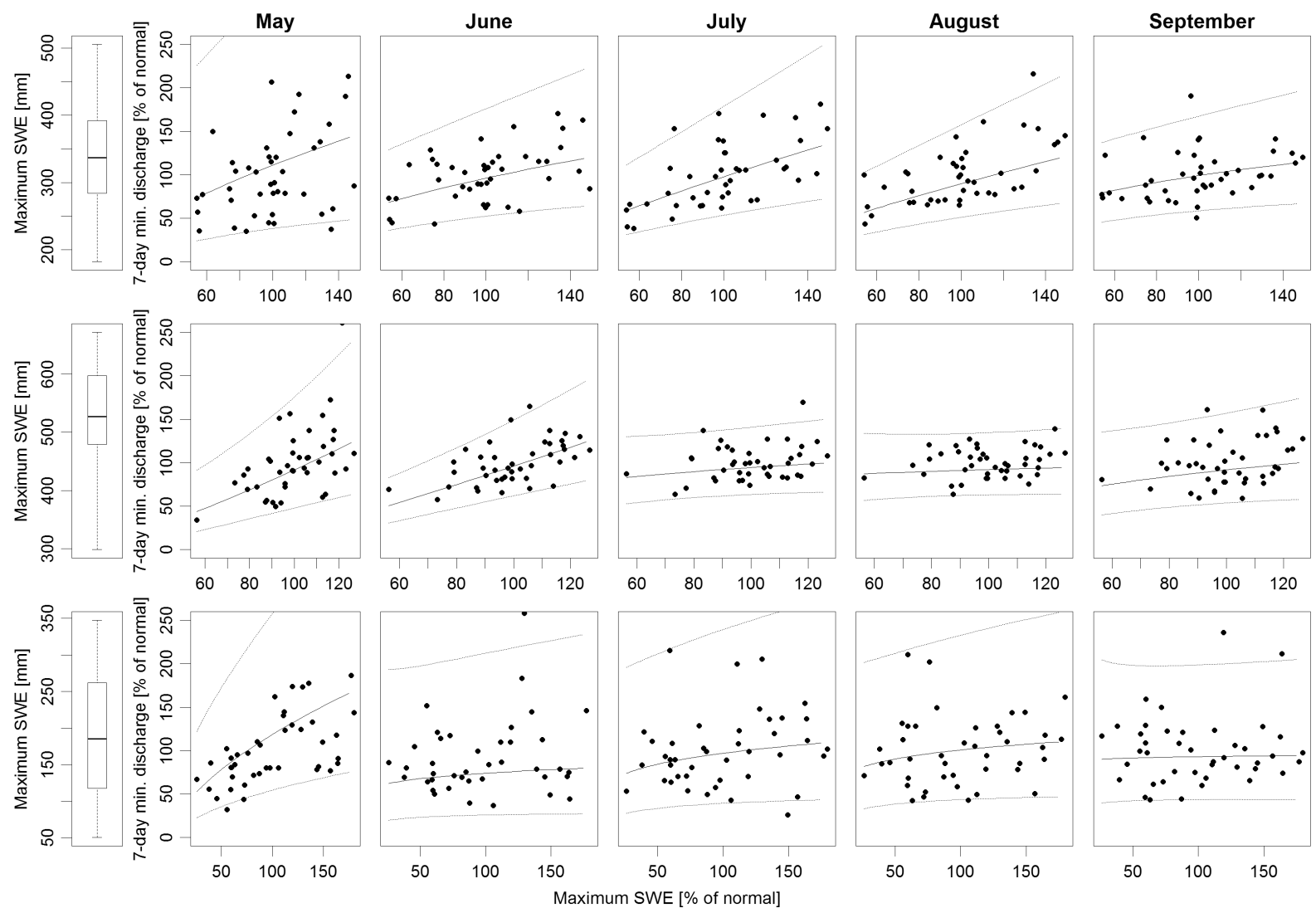

Figure 3. Dependence of 7-day minimum discharge on maximum SWE for individual months. Top panels: Ova da Cluozza River representing a high-elevation catchment with a mean catchment elevation of $2361 \mathrm{~m}$ a.s.l., correlations from May to September are statistically significant (0.05 level). Middle panels: Simme River, representing a middle-elevation catchment with a mean catchment elevation of $1632 \mathrm{ma} . \mathrm{s} .1$, correlations from May to June are significant. Bottom panels: Sitter River as a representative of a low-elevation catchment with a mean catchment elevation of $1247 \mathrm{~m}$ a.s.l., only the correlation in May is significant. Solid lines represent the low flow occurring with a $50 \%$ probability, dotted lines represent the $95 \%$ prediction interval. The boxes represent the 25 and $75 \%$ quantiles, with the thick line showing the median, and the whiskers represent minimum and maximum values.

and the elasticity index of the middle-elevation catchments was higher than for the low-elevation catchments. While the spread of the elasticity indices per elevation class was about equal for high- and middle-elevation catchments the spread for the low-elevation increased progressing from month to month. This means that the general sensitivity to SWE is lower for lower- and middle-elevation catchments than for high-elevation catchments and decreases for each class progressing from June to September.

Theil-Sen slopes for each catchment and for every week from the beginning of May to the end of September, allowed an analysis of the sensitivity in terms of the memory effect of each catchment (Fig. 5). These weekly slopes describe how long water from snowmelt contributes to runoff formation and thus how long snowmelt affects low flows. With this approach, a significant effect of snow on low flows became visible during the whole summer and until September for catchments higher than $2000 \mathrm{~m}$ a.s.l. (Fig. 5). Snow affected low flows until July in catchments with mean catchment elevation in the range of 1500 to $2000 \mathrm{~m}$ a.s.l. However, snow did not affect summer low flow (July to September) in catchments lower than $1500 \mathrm{~m}$ a.s.l. Here, snow affected low flows during May and June only, which is probably caused mostly by lower SWE (maximum less than $250 \mathrm{~mm}$ ).

There was a clearly longer snowmelt contribution to minimum discharges in higher-elevation catchments even when different melt-out dates (black points in the Fig. 5) were considered. This could be related to more available water released from snow in higher-elevation catchments despite their steeper slopes and shallow soils. The negative correlations in some of the lower-elevation catchments (usually not statistically significant) indicate a mixed effect of snow and liquid precipitation in the warm season.

Additionally, Theil-Sen slopes for each catchment and for every week from the beginning of May to the end of September were calculated and set in context to the melt-out days only for situations with dry preceding conditions, i.e. when liquid precipitation prior to minimum discharge in a specific 

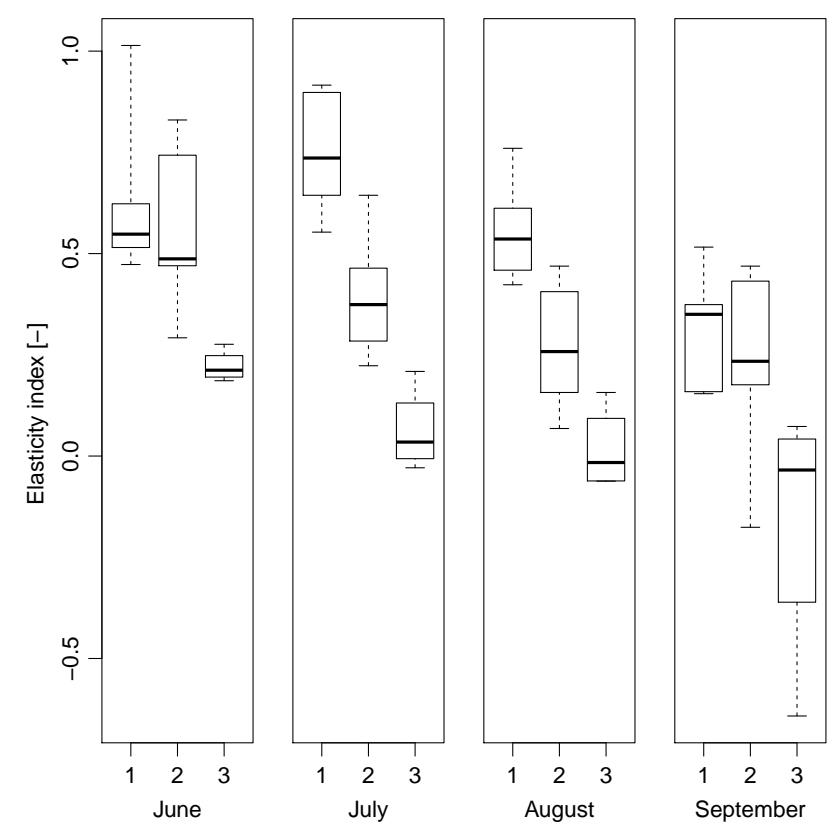

Figure 4. Elasticity index for all catchments classified according to elevation describing the sensitivity of 7-day minimum discharge on maximum SWE for individual months. Elevation classes on $x$ axis: 1, catchments with mean elevation higher than $2000 \mathrm{~m}$ a.s.1.; 2, catchments with mean elevation between 1300 and 2000 m a.s.l.; 3, catchments with mean elevation between 850 and $1300 \mathrm{~m}$ a.s.l. The boxes represent the 25 and $75 \%$ quantiles, with the thick line showing the median, and the whiskers represent minimum and maximum values.

week was below average (results not shown in the paper). Considering only these situations, the sensitivity of minimum discharges to maximum SWE increased. This was due to the reduced influence of liquid precipitation in the warm season. As a consequence, snow became more important and thus any decrease/increase of snow storage in individual year resulted in a more sensitive response of minimum discharge.

The sensitivity as described by Theil-Sen slopes of individual catchments strongly depends on catchment properties, such as mean catchment elevation, maximum SWE and $S / P$ (Table 3). The significant positive correlations (Table 3) imply that the sensitivity of minimum discharge to maximum SWE increases with increasing value of the catchment property. Summer minimum discharges in higher-elevation catchments with steep slopes, high drainage density and high maximum SWE were more sensitive to maximum SWE changes than minimum discharges in lower and less steep catchments with lower drainage density and low maximum SWE (Table 3). These correlations clearly varied for different months and reached their maximum in July and August and they decreased in September. Maximum SWE influences mainly the volume of water in the groundwater zone. Elevation influences mainly the timing of snowmelt with later snowmelt onset at higher elevations. Thus, the water inflow into the
Table 3. Spearman rank correlation coefficients for the relation between catchment properties and Theil-Sen slopes (TS), which were computed for assessing the low-flow sensitivity to peak SWE. Statistically significant correlations (at the 0.05 level) are shown in bold.

\begin{tabular}{lrrrrr}
\hline Catchment property & TS May & TS Jun & TS Jul & TS Aug & TS Sep \\
\hline Area & 0.18 & 0.02 & -0.12 & -0.17 & 0.16 \\
Elevation & -0.09 & $\mathbf{0 . 5 8}$ & $\mathbf{0 . 8 8}$ & $\mathbf{0 . 8 0}$ & 0.52 \\
Slope & 0.07 & 0.28 & $\mathbf{0 . 8 3}$ & $\mathbf{0 . 7 3}$ & 0.49 \\
Drainage density & -0.42 & 0.52 & $\mathbf{0 . 6 0}$ & $\mathbf{0 . 7 4}$ & 0.42 \\
Maximum SWE & 0.00 & $\mathbf{0 . 6 7}$ & $\mathbf{0 . 6 0}$ & $\mathbf{0 . 5 7}$ & $\mathbf{0 . 6 6}$ \\
$S / P$ & -0.13 & $\mathbf{0 . 6 2}$ & $\mathbf{0 . 8 7}$ & $\mathbf{0 . 8 4}$ & $\mathbf{0 . 5 4}$ \\
Winter precipitation & 0.41 & -0.29 & -0.32 & -0.39 & -0.17 \\
\hline
\end{tabular}

groundwater zone occurs later in spring and it is distributed over a longer time period. Which is why snow affects low flows even in late summer. Maximum SWE shows significant correlations in June through September, while winter precipitation was not significantly correlated to the Theil-Sen slopes (Table 3). Additionally, Spearman rank correlations were not significant with regard to catchment area. However, some of variables used are mutually dependent (elevation, slope, drainage density, maximum SWE and $S / P$ ).

The elasticity calculated for the $50 \%$ probability of prediction enables us to describe the impact of future changes of snowpack (Fig. 6). The elasticity index in this study is usually lower than 1, which means that a particular percentage change in maximum SWE causes a lower percentage change of minimum discharge. For catchments higher than 2000 m a.s.l., every decrease of the maximum SWE by $10 \%$ will cause a decrease of minimum discharge in July by 6-9\% (Fig. 6, top right panel). This means that the decrease of minimum discharge is almost proportional to the decrease of SWE in some cases (Ova Da Cluozza and Ova dal Fuorn). For catchments with a mean elevation between 1500 and $2000 \mathrm{~m}$ a.s.l., the decrease of minimum discharge ranges from $2 \%$ (Grande Eau) to 5\% (Simme). The lowest catchments are characterized with even lower values indicating that any decrease of maximum SWE will not significantly affect low flows at least from July to September. However, there is some small effect during June (Fig. 6, top left panel). Generally, the sensitivity of low flows to the change of SWE increases with elevation and decreases from June to September. However, the elasticity is not linear and the decrease of low flows accelerates with decreasing SWE.

Maximum SWE for each catchment impacted the DOY with 7-day minimum discharge (Fig. 7). Our hypothesis was that minimum summer discharge would occur later in the year for higher maximum SWE. However, later lowflow occurrence may be additionally influenced by a later melt-out. Low flows occurred in September and October for higher-elevation catchments with a higher SWE maximum (Fig. 7, brown points). In contrast, July and August are typical months for low-flow occurrences for lower-elevation 


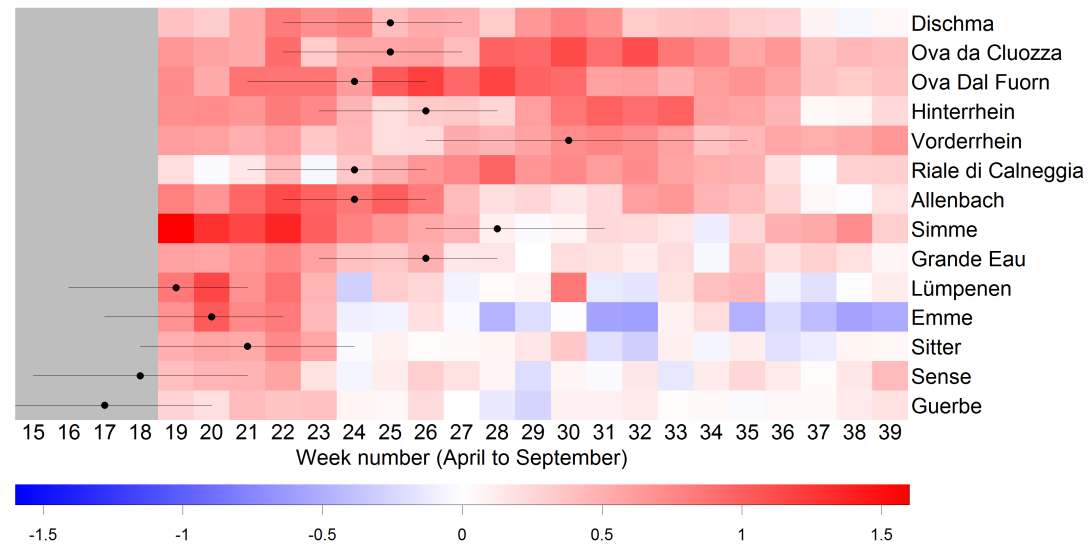

Figure 5. Dependence of 7-day minimum discharge on maximum SWE for all studied catchments (sorted by elevation from highest to lowest) for individual weeks from the beginning of May (week 19) to the end of September (week 39). April (weeks 15-18) was not included in calculation. Colour key provides Theil-Sen slope values. Red indicates positive effect of SWE on minimum discharge (positive slopes), blue indicates negative effect of SWE on minimum discharge (negative slopes). Black points indicate average week of melt-out, whiskers represent 10 and $90 \%$ quantiles.
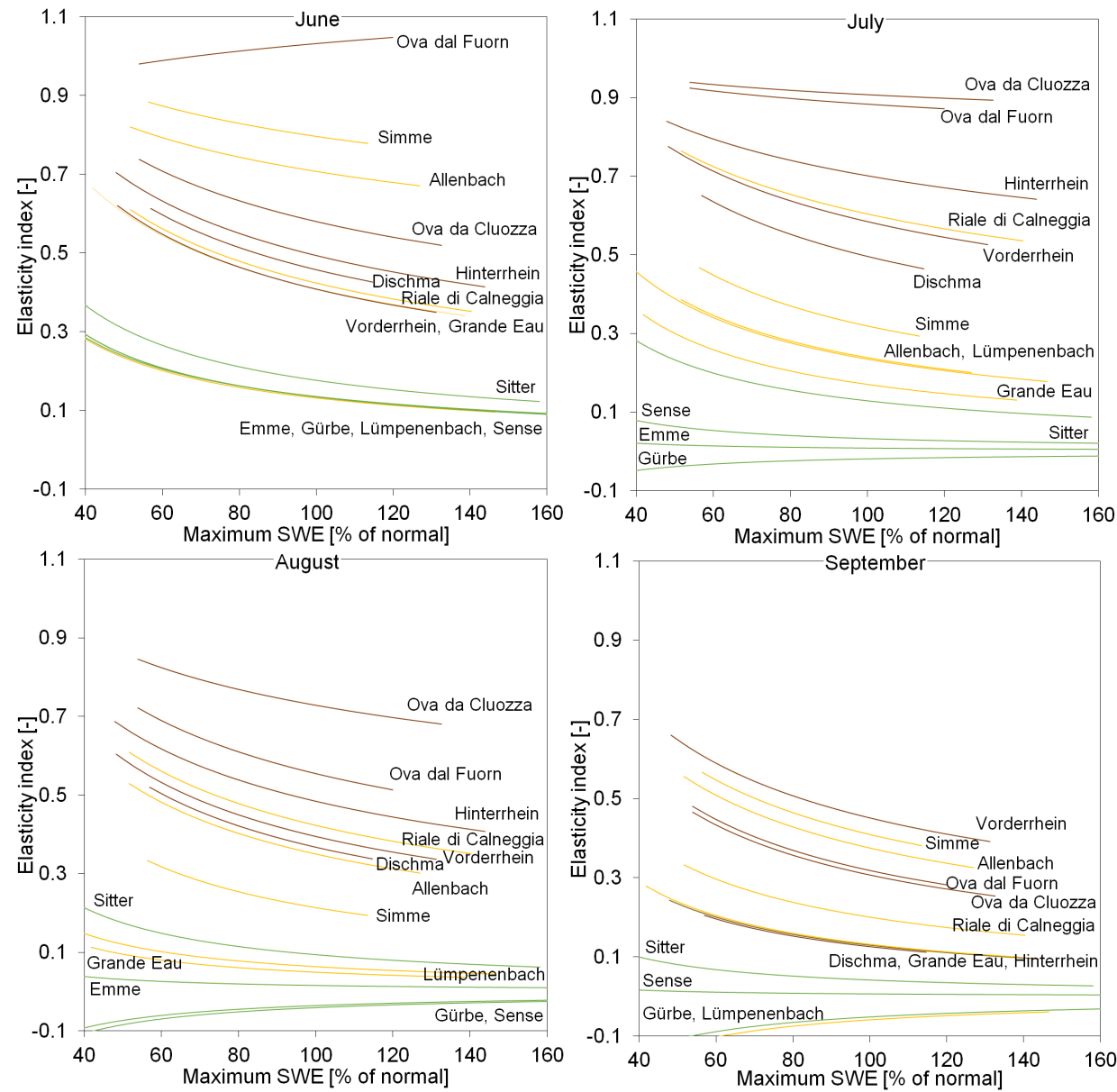

Figure 6. Elasticity index showing the sensitivity of minimum discharge to changes in SWE. The index was calculated from the $50 \%$ probability of prediction. Line colours indicate the catchment group according to mean elevation (dark brown: $>2000 \mathrm{~m}$ a.s.1.; light brown: 1300-2000 m a.s.1.; green: < 1300 m a.s.1.). 


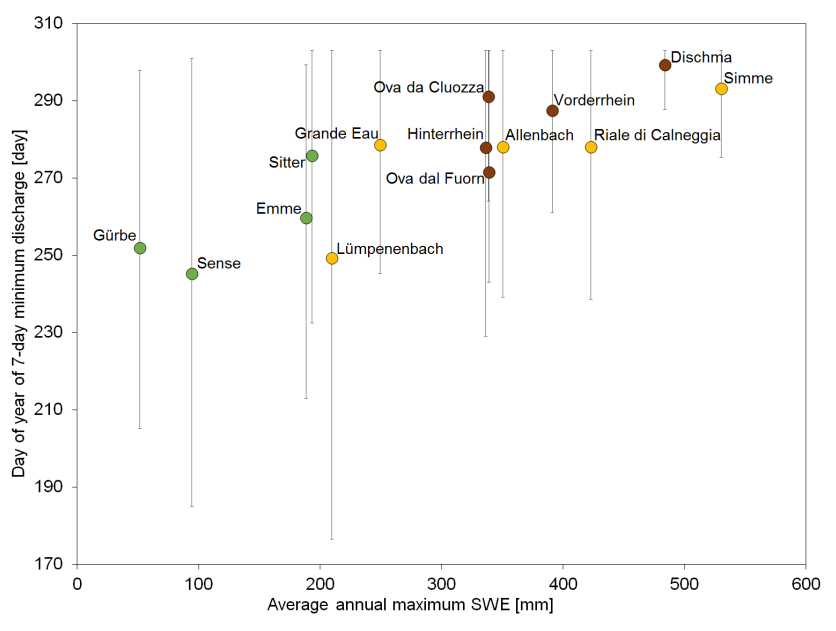

Figure 7. Day of year (DOY) with 7-day minimum discharge against long-term mean annual maximum SWE. Colour circles represent catchment mean and whiskers represent 10 and $90 \%$ quantiles. The DOY " 1 " represents the first day of calendar year (1.1) and the DOY " 365 " represents 31.12. The colour of the circle indicates the catchment group according to mean elevation (dark brown: > 2000 ma.s.1.; light brown: 1300-2000 m a.s.l.; green: $<1300$ m a.s.1.).

catchments with lower SWE maximum (Fig. 7, green points). On average, every decrease in maximum SWE by $100 \mathrm{~mm}$ resulted in discharge minima occurring about 12 days earlier. However, inter-annual variability markedly increases in lower-elevation catchments indicating an increasing role of summer precipitation. Thus, the relation between maximum SWE and the DOY of 7-day minimum discharge cannot be used predictively. Additionally, the Spearman rank correlations between maximum SWE and the DOY with 7-day minimum discharge were significant only in some higher- and middle-elevation catchments (above $1500 \mathrm{~m}$ a.s.l.) and their values were rather low (detailed results not shown).

\subsection{Combined effect of snow conditions and preceding precipitation on summer low flows}

The relation between snow and minimum discharge during the summer period is not often clear and may be overlaid by several other factors, mostly precipitation after melt-out. To demonstrate the combined effect of snow and precipitation on summer low flows, three snow-dominated catchments at high and middle elevations (Ova da Cluozza, Vorderrhein and Lümpenenbach) were selected as typical representatives and then further analysed.

For low $C_{\text {PI }}$ years, snow became a better predictor to explain the variability of minimum discharge indicated by steeper regression slopes and higher coefficients of Spearman rank correlation (Fig. 8, top panels). Minimum discharges did not decrease much, with a low SWE and high $C_{\mathrm{PI}}$ (top plots, dashed lines). However, snow was more important for low $C_{\mathrm{PI}}$ years, where minimum discharges were more sensitive to the change of summer precipitation (top plots, solid lines).

The minimum discharge decreased significantly in years with lower than average maximum SWE and average preceding precipitation compared to years with higher than average SWE maximum and same amount of preceding precipitation (Fig. 8, bottom panels). For the Ova da Cluozza catchment, as an example, and considering only years with above-average SWE maximum, there is a $50 \%$ probability that given an average preceding precipitation there will be a 7-day minimum discharge equal or higher than $107 \%$ of its normal in July. In contrast, considering years with below-average SWE maximum, the 7-day minimum discharge will decrease to $75 \%$ of its normal level. Similar changes were detected both in higher-elevation catchments and lower-elevation catchments, although in the latter this decrease is somewhat smaller.

The combined effect of snow and liquid precipitation on low flows was analysed using "score plots". In these plots the position of each catchment is shown according to its average influence of snow and precipitation on the 7-day minimum discharge separately for the period from June to September (Fig. 9). Points located below the $y=x$ line indicate catchments where snow has a stronger effect on low flows compared to rain. Catchments with a mean elevation higher than $1600 \mathrm{~m}$ a.s.l. in June and July and higher than $2000 \mathrm{~m}$ a.s.l. in August are typical representatives for a stronger effect of snow (Fig. 9, brown points). Points located above the line indicate catchments with a stronger effect of rain on low flows (lower-elevation catchments in June, July and August and all catchments in September). Progressing from June to September the relative effect on low flows shifted from the highestelevation catchments showing a stronger effect of snow and a weaker effect of liquid precipitation which is reversed by September.

\section{Discussion}

\subsection{The role of catchment properties}

Based on our results it seems that dependencies between predictors and response variables may be connected to catchment properties and climate drivers to some degree, such as elevation and thus maximum SWE and $S / P$. However, the variability of low flows cannot be explained by one single parameter as indicated by relatively low values of Spearman rank correlation.

The correlation of the dependencies of summer low flows on catchment elevation can be explained by lower air temperature at higher elevation and thus more snow accumulation and may be supported by results of Birsan et al. (2005) and Staudinger et al. (2015) in Swiss catchments. Staudinger et al. (2015) showed that higher-elevation and steeper catch- 

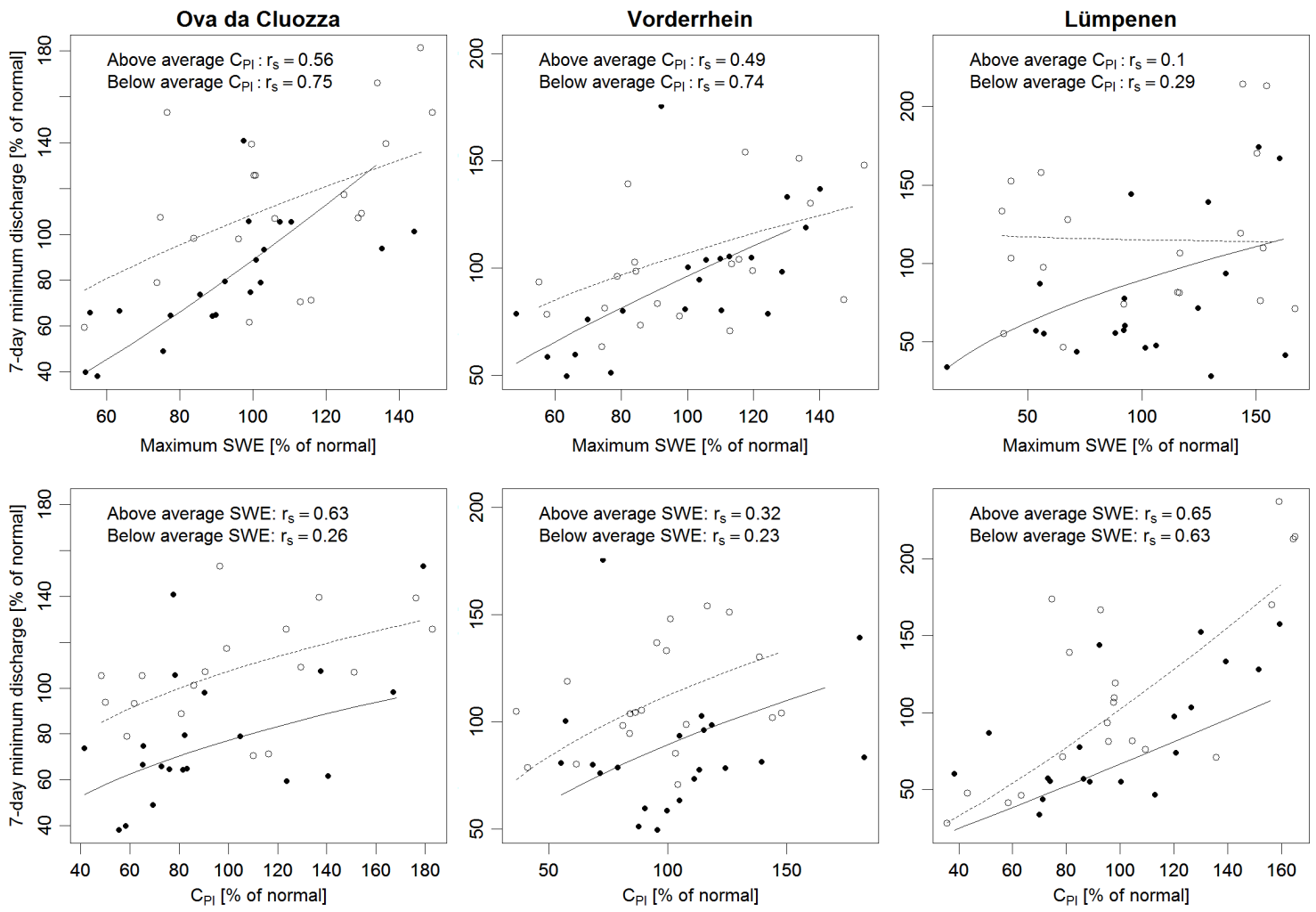

Figure 8. Top panels: 7-day minimum discharge in July against maximum SWE for years grouped according to the current precipitation index $C_{\mathrm{PI}}$. Bottom panels: 7-day minimum discharge in July against current precipitation index $C_{\mathrm{PI}}$ for years grouped according to maximum SWE. Lines represent the minimum discharge occurring with a $50 \%$ probability; $r_{\mathrm{s}}$ represents Spearman rank correlation coefficient. Transparent circles and dashed lines indicate years with above-average values and black points and solid lines indicate years with below-average values.

ments were less sensitive to droughts mainly because of an increasing snow influence but also because of potentially larger storages for the higher-elevation catchments of the selection. Our results showed that this sensitivity might increase with decreasing SWE especially in the highestelevation catchments.

The elevation was also related to the memory effect of individual catchments which was generally longer for the highest-elevation catchments than for middle- or lowelevation catchments. However, even with the highestelevation catchments, we did not find any significant correlations of snow and minimum discharges in October and later. In contrast, Godsey et al. (2014) found significant correlations even with the previous year's snowpack for some catchments in the western United States.

A longer memory effect in catchments with higher elevation is not only connected to higher snowpack accumulations but also to the simple fact that snowmelt occurs later in spring and persists longer compared to catchments at lower elevations (often until late spring or even early summer). The dependence of the DOY with minimum 7-day discharge on the DOY of maximum SWE was confirmed in our study. Similar dependences were found also in Whitaker et al. (2008), using the timing of the first significant snowmelt event instead of the DOY of maximum SWE. A negative trend in the number of days with discharge below a specified threshold in the case of increasing maximum SWE was proved. A $25 \%$ quantile of discharge from May to October was used in this study. A $10 \%$ quantile was also tested and found to have only minor impact on the results.

As documented by Beaulieu et al. (2012) in British Columbia, snow from headwater parts of catchments contributes significantly to base flow in lower parts of the catchments during summer. Earlier snowmelt onset and thus decrease of minimum streamflow has been observed (Jefferson, 2011) and a further shift of snowmelt towards earlier spring is predicted (Barnett et al., 2005; Bavay et al., 2009; Hanel et al., 2012; Godsey et al., 2014; Blahusiakova and Matouskova, 2015).

Of course there are many other factors together with snow in winter that influence and can explain low-flow conditions in summer. For instance, evapotranspiration may change from year to year. However, water balance component estimates for the entire Switzerland during the last 100 years show that annual precipitation and runoff vary far more than evaporation (Hubacher and Schädler, 2010). Additionally, 

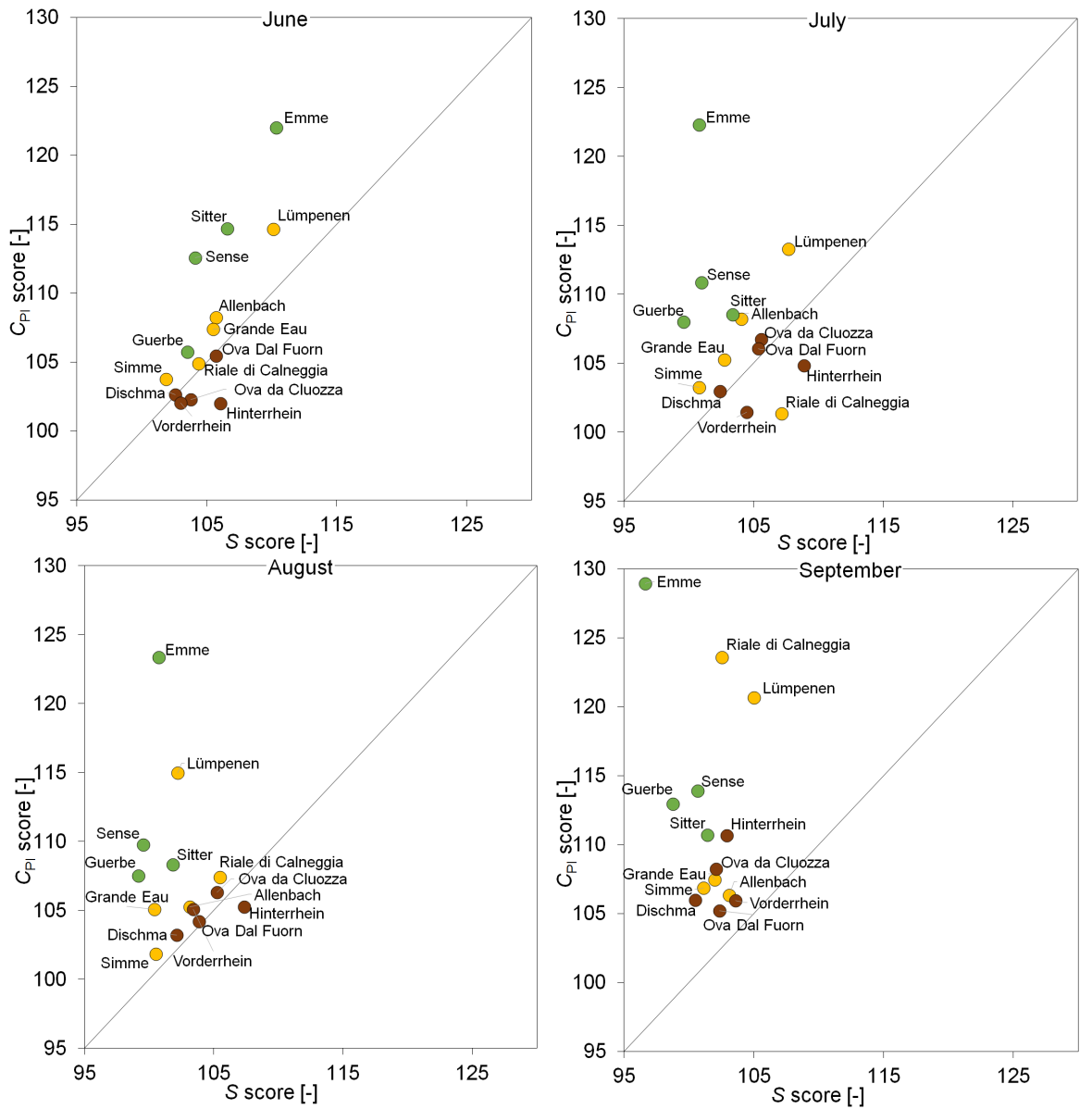

Figure 9. Score plots indicating the combined effect of snow and liquid precipitation on low flows in the different months (four plots for June to September). Points below the one-to-one line indicate catchments with a stronger effect of maximum SWE on low flows compared to spring and summer precipitation (expressed as $C_{\mathrm{PI}}$ ) and vice versa. The colour of the circle indicates the catchment group according to mean elevation (dark brown: > 2000 m a.s.l.; light brown: 1300-2000 m a.s.1.; green: < $1300 \mathrm{~m}$ a.s.1.).

our results using data from PREVAH model proved that the inter-annual variability of ET in the warm season is much a lower than inter-annual variability of precipitation and maximum SWE (Fig. 10). Thus, the ET had a smaller impact on the inter-annual variability of 7-day minimum discharges compared to the impact of precipitation and maximum SWE. Although this is a relatively simple approach, it shows that ET likely is a less useful predictor to explain inter-annual variability of low flows compared to the other predictors. However, the within-year variation of ET is of course important to explain the occurrence of low flows (Teuling et al., 2013).

We tested also drainage density to account for landscape draining properties (e.g. Tague and Grant, 2004) and found significant correlation of low-flow sensitivity to the change of maximum SWE (Table 3). Draining properties together with catchment storage properties may help understanding the process causality leading to summer low flow. Combining this kind of catchment properties with the snow information might be useful for prediction. However, in this study we explored and quantified the general dependency and sensitivity to winter snowpack in humid regions.

However, the results presented in this study do not explain the process causality in detail. It means that we quantified the relations based on data we used, but process-based understanding at the catchment scale is limited and has to be further investigated.

\subsection{Influence of changing snow conditions}

The influence of snow conditions on summer low flow will likely decrease due to predicted air temperature increase during winter and thus the decrease of $S / P$ ratio and SWE at middle elevations. The snow fraction has an important effect on not only annual discharge (Berghuijs et al., 2014; Speich et al., 2015; Zhang et al., 2015) but also on summer low flows as documented by Godsey et al. (2014) in the western United States and Laghari et al. (2012) in Austria. Our results are similar for high- and mid-elevation catchments in 

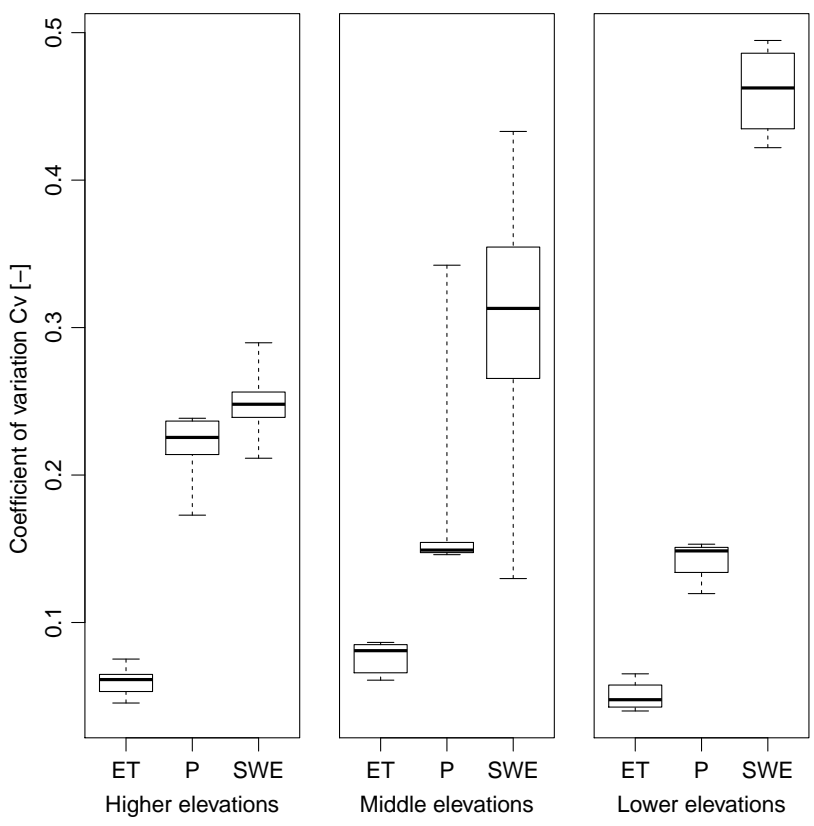

Figure 10. Inter-annual variability of seasonal actual evapotranspiration (ET), seasonal precipitation $(P)$ and maximum SWE evaluated by the coefficient of variation, $C_{\mathrm{V}}$. The catchments were grouped by elevation; left, higher elevations: catchments with mean elevation higher than $2000 \mathrm{~m}$ a.s.l.; middle, middle elevations: catchments with mean elevation between 1300 and 2000 ma.s.l.; right, lower elevations: catchments with mean elevation between 850 and $1300 \mathrm{~m}$ a.s.l. The boxes represent the 25 and $75 \%$ quantiles, with the thick line showing the median, and the whiskers represent minimum and maximum values.

Switzerland, and based on these studies, we may conclude that summer low flows are significantly sensitive to any SWE changes. Although our study did not focus on existing trends in data, we expect a reducing effect of snow on late summer low flows in the highest-elevation catchments. This reduction might increase problems with water availability in affected regions.

We did not explore possible impact of climate change on SWE and minimum discharges, such as relations between possible warming in the cold season and minimum discharges in the warm season, or explore whether any SWE decrease will occur related to it. However, if a SWE decrease occurs, then the same percentage decrease of SWE in higherelevation catchments will result in a stronger percentage decrease of minimum discharges than the same percentage decrease of SWE in lower-elevation catchments (see Fig. 6 showing the elasticity). This means that any interpretation going towards the possible effect of increasing air temperature might be misleading since we did not explore the relation between temperature increase and SWE decrease (e.g. due to decrease in snowfall fraction). This interpretation would be difficult especially in the highest-elevation catchments where air temperature in the cold period is well below $0{ }^{\circ} \mathrm{C}$ and a small air temperature increase would not result in a change of snowfall fraction (in contrast to low-elevation catchments where air temperature in cold periods is often around $0{ }^{\circ} \mathrm{C}$ ).

In this study we looked at catchment mean elevations and for some analyses we also classified catchments as high-, mid- or low-elevation catchments. In practice this might be oversimplified as there is generally a large gradient of precipitation and $S / P$ ratios across elevation. Hence, also depending on the percentage of a catchment that is well below $0{ }^{\circ} \mathrm{C}$ for most of the winter even with warming conditions, the effect of SWE changes will be more or less strong. Nevertheless, we argue that the quantification method introduced in this study could be applied also for a more discretized setup with regard to relevant elevation zones.

\subsection{Combined effect of snow and precipitation}

The correlation between minimum discharge and maximum SWE considering years with little rain was higher than in years with a lot of rain. Low flows are usually higher during years with above-average snow conditions. Even in the case of low antecedent precipitation, low flow was higher than in years with below-average snow conditions. Therefore, snow plays an important role, although below-average snow conditions do not necessarily indicate below-average low flows. Preceding precipitation seems to be more important in this case. Because of the combined effect of snow and summer precipitation on summer low flows, snow-related parameters cannot fully explain the inter-annual variability of low flows in humid regions as documented by Godsey et al. (2014) for strongly seasonal regions even for the highestelevation catchments. Nevertheless, most of detected trends in our study were significant at less than the 0.05 level, showing the significant influence of snow on summer low flows.

The decrease of maximum SWE and snowfall fraction increased the relative importance of rain during summer. Our results showed that the continuous decrease of maximum SWE and snowfall fraction in the future might increase the sensitivity of catchments at mid- and high elevations to hydrological droughts. This conclusion is in accordance with results of Birsan et al. (2005).

We chose the period from May to September to show the changing importance of snow contribution to low flows in different catchments, both at lower and higher elevations. We also tested the effect of maximum SWE on summer minimum discharge (June-August, not shown in this paper). The results for most of catchments are very similar to existing relations calculated for August because most of summer minimum discharges occur in August. Clearly we see the lowest summer flow as a compelling response variable, given the water management interest and possible issues connected to it. However, for the development of the role of snow compared to liquid precipitation this one response variable is not sufficient. 
Our results do not provide a general answer to the question of whether snow storage is more important than precipitation. Due to moderate humid climate in Switzerland with precipitation almost equally distributed in a year (opposite to western United States), the aim was to show the combined effect of snow and liquid precipitation and their changing role in time (in different months) and in catchments with different elevation. Summer precipitation in Switzerland is relatively higher than summer precipitation in the western United States and, as shown in our study, summer precipitation dominates over the effect of snow, especially with an increasing time from the snowmelt period and with decreasing elevation. This combined effect explains the contrary results for the western United States and Switzerland.

\subsection{Practical use of a quantification of snow influence on summer low flows}

We used winter precipitation as a predictor and we expected similar results as using maximum SWE as predictor. Winter precipitation (from November to April) is highly correlated with SWE and we expect increasing mutual correlation for higher-elevation catchments with higher $S / P$. Despite higher correlations in some cases (Fig. 2), we consider winter precipitation to be less suitable as a predictor than maximum SWE. Maximum SWE showed significant correlations with the Theil-Sen slopes in June through September, while winter precipitation was not significantly correlated to any of these sensitivity parameters (Table 3). Additionally, winter precipitation is not corrected for undercatch of snowfall. Thus, we expect larger errors varying between stations according to site conditions and wind speed. Given these facts and given that maximum SWE showed better prediction ability compared to winter precipitation for higher-elevation catchments, maximum SWE seems to be suitable predictor for forecast models. Hence, we believe that SWE data offer a chance to improve hydrological prediction models.

Our results quantified the effect of snow on minimum discharges when liquid precipitation is below average (or opposite, when SWE is below average) as documented in Fig. 8. This could increase the reliability of predictions of minimum discharge during summer. Additionally, we provided information about sensitivity of low flow in individual catchments to changes in maximum SWE using prediction intervals showing the $50 \%$ probability as well as prediction bands enabling the prediction of future observation. With this approach, it was possible to quantify not only the effect of snow storage on minimum discharge, but also on other low-flow parameters, such as length of the period with minimum discharge, DOY of minimum discharge occurrence and number of days below a specified runoff threshold.

We used new SWE data covering the entire Switzerland. From our study we see a big potential to use these data for instance to regionalize the catchment sensitivity and the length of snowmelt contribution to runoff in poorly gauged areas.

\section{Conclusions}

In this study we described and quantified the influence of winter and spring snow conditions on summer low flows in 14 Swiss Alpine and pre-Alpine catchments over the last 42 years. Specifically, we investigated the memory effect related to snow influence in runoff and the sensitivity of the catchments to low-flow reduction due to any change of snowpack. The main conclusions were the following.

Snowmelt significantly affected minimum discharge in May to September (with decreasing importance) in study catchments higher than 2000 ma.s.l., up to, in July and August in mid-elevation catchments and only in June and July in the lowest-elevation catchments. The sensitivity of minimum discharges to maximum annual SWE was higher for catchments at higher elevation when looking on relative changes in minimum discharge and maximum SWE.

Low flows occurred later in the year for years with aboveaverage snow accumulations. However, the Spearman rank correlation between maximum SWE and the DOY with 7day minimum discharge was significant only in some higherand middle-elevation catchments (mean catchment elevation above $1500 \mathrm{~m}$ a.s.1.). The differences between the catchments were determined by both higher maximum SWE and later melt-out in the higher-elevation catchments.

Maximum SWE showed the best prediction ability from all winter-related predictors used in this study especially for higher-elevation catchments of our selection. Applicable results were achieved also with winter precipitation (November-April). However, winter precipitation is not suitable to describe the catchment sensitivity and they are not corrected for undercatch. Thus, using maximum SWE is recommendable for sensitivity studies.

Snow and summer precipitation had a combined effect on summer low flows, and snow accumulation alone cannot explain the inter-annual variability of low flows even in highelevation catchments. Snow was a better predictor for the variability of low flows when only years with lower than average preceding precipitation were considered. However, even if both snow and liquid precipitation are considered, there is still some portion of inter-annual variability which cannot be explained by these two predictors.

Summer low flows in the study catchments were significantly sensitive to any SWE changes. Although our study did not address climate change impacts explicitly, a reduced effect of snow on late summer low flows in the highest- and middle-elevation catchments can be expected due to the predicted decrease of snowfall fraction in the future. As a consequence, the sensitivity of catchments at mid- and high elevations to meteorological droughts might increase.

Author contributions. M. Zappa and J. Seibert initiated the project. M. Jenicek developed the methodology (with contributions of Jan Seibert) and performed all analyses. M. Zappa, M. Staudinger and T. Jonas prepared input meteorological data used for analyses. 
M. Jenicek prepared the paper with substantial contributions from all co-authors.

Acknowledgements. Support from the Swiss National Research Programme Sustainable Water Management (NRP 61, project DROUGHT-CH) and the Czech Science Foundation (GACR 13$32133 \mathrm{~S}$, project Headwaters) is gratefully acknowledged. The authors also thank SCIEX - Scientific Exchange Programme NMS.CH for the support of the first author during his postdoc stay at the University of Zurich. The contribution of M. Zappa was supported by the Swiss National Science Foundation SNF through the Joint Research Projects (SCOPES) Action (Grant IZ73Z0_152506). Many thanks to Tracy Ewen for improving the English of the paper.

Edited by: A. Van Loon

\section{References}

Andréassian, V., Coron, L., Lerat, J., and Le Moine, N.: Climate elasticity of streamflow revisited - an elasticity index based on long-term hydrometeorological records, Hydrol. Earth Syst. Sci. Discuss., 12, 3645-3679, doi:10.5194/hessd-12-3645-2015, 2015.

Barnett, T. P., Adam, J. C., and Lettenmaier, D. P.: Potential impacts of a warming climate on water availability in snow-dominated regions, Nature, 438, 303-309, doi:10.1038/nature04141, 2005.

Bavay, M., Lehning, M., Jonas, T., and Löwe, H.: Simulations of future snow cover and discharge in Alpine headwater catchments, Hydrol. Process., 23, 95-108, doi:10.1002/hyp.7195, 2009.

Beaulieu, M., Schreier, H., and Jost, G.: A shifting hydrological regime: a field investigation of snowmelt runoff processes and their connection to summer base flow, Sunshine Coast, British Columbia, Hydrol. Process., 26, 2672-2682, doi:10.1002/hyp.9404, 2012.

Berghuijs, W. R., Woods, R. A., and Hrachowitz, M.: A precipitation shift from snow towards rain leads to a decrease in streamflow, Nat. Clim. Change, 4, 583-586, doi:10.1038/NCLIMATE2246, 2014.

Birsan, M. V., Molnar, P., Burlando, P., and Pfaundler, M.: Streamflow trends in Switzerland, J. Hydrol., 314, 312-329, doi:10.1016/j.jhydrol.2005.06.008, 2005.

Blahusiakova, A. and Matouskova, M.: Rainfall and runoff regime trends in mountain catchments (Case study area: the upper Hron River basin, Slovakia), J. Hydrol. Hydromech., 63, 183-192, doi:10.1515/johh-2015-0030, 2015.

Cayan, D. R., Riddle, L. G., and Aguado, E.: The influence of precipitation and temperature on seasonal streamflow in California, Water Resour. Res., 29, 1127-1140, doi:10.1029/92WR02802, 1993.

Cayan, D. R., Kammerdiener, S. A., Dettinger, M. D., Caprio, J. M., and Peterson, D. H.: Changes in the Onset of Spring in the Western United States, B. Am. Meteorol. Soc., 82, 399-415, doi:10.1175/1520-0477(2001)082<2265:CAACOC > 2.3.CO;2, 2001.

Dai, A.: Temperature and pressure dependence of the rain-snow phase transition over land and ocean, Geophys. Res. Lett., 35, L12802, doi:10.1029/2008GL033295, 2008.
Day, C. A.: Modelling impacts of climate change on snowmelt runoff generation and streamflow across western US mountain basins: a review of techniques and applications for water resource management, Prog. Phys. Geogr., 33, 614-633, doi:10.1177/0309133309343131, 2009.

Earman, S., Campbell, A. R., Phillips, F. M., and Newman, B. D.: Isotopic exchange between snow and atmospheric water vapor: Estimation of the snowmelt component of groundwater recharge in the southwestern United States, J. Geophys. Res.-Atmos., 111, D09302, doi:10.1029/2005JD006470, 2006.

Feiccabrino, J. and Lundberg, A.: Precipitation Phase Discrimination in Sweden, in: 65th Eastern Snow Conference, 2830 May 2008, Fairlee (Lake Morey), Vermont, USA, 239-254, 2008.

Feng, S. and Hu, Q.: Changes in winter snowfall/precipitation ratio in the contiguous United States, J. Geophys. Res.-Atmos., 112, D15109, doi:10.1029/2007JD008397, 2007.

Frei, C.: Interpolation of temperature in a mountainous region using nonlinear profiles and non-Euclidean distances, Int. J. Climatol., 34, 1585-1605, doi:10.1002/joc.3786, 2014.

Frei, C. and Schär, C.: A precipitation climatology of the Alps from high-resolution rain-gauge observations, Int. J. Climatol., 18, 873-900, doi:10.1002/(SICI)10970088(19980630)18:8<873::AID-JOC255>3.0.CO;2-9, 1998.

Godsey, S. E., Kirchner, J. W., and Tague, C. L.: Effects of changes in winter snowpacks on summer low flows: case studies in the Sierra Nevada, California, USA, Hydrol. Process., 28, 50485064, doi:10.1002/hyp.9943, 2014.

Gurtz, J., Baltensweiler, A., and Lang, H.: Spatially distributed hydrotope-based modelling of evapotranspiration and runoff in mountainous basins, Hydrol. Process., 13, 2751-2768, doi:10.1002/(SICI)1099-1085(19991215)13:17<2751::AIDHYP897>3.0.CO;2-O, 1999.

Hanel, M., Vizina, A., Máca, P., and Pavlásek, J.: A Multi-Model Assessment of Climate Change Impact on Hydrological Regime in the Czech Republic, J. Hydrol. Hydromech., 60, 152-161, doi:10.2478/v10098-012-0013-4, 2012.

Hubacher, R., Schädler, B.: Wasserhaushalt grosser Einzugsgebiete im 20. Jahrhundert, Tafel 6.6, in: Hydrologischer Atlas der Schweiz (HADES) edited by: Weingartner, R. and Spreafico, M., Bundesamt für Umwelt, Bern, 2010.

Jefferson, A. J.: Seasonal versus transient snow and the elevation dependence of climate sensitivity in maritime mountainous regions, Geophys. Res. Lett., 38, L16402, doi:10.1029/2011GL048346, 2011.

Jonas, T., Marty, C., and Magnusson, J.: Estimating the snow water equivalent from snow depth measurements in the Swiss Alps, J. Hydrol., 378, 161-167, doi:10.1016/j.jhydrol.2009.09.021, 2009.

Jörg-Hess, S., Fundel, F., Jonas, T., and Zappa, M.: Homogenisation of a gridded snow water equivalent climatology for Alpine terrain: methodology and applications, The Cryosphere, 8, 471485, doi:10.5194/tc-8-471-2014, 2014.

Jörg-Hess, S., Griessinger, N., and Zappa, M.: Probabilistic Forecasts of Snow Water Equivalent and Runoff in Mountainous Areas, J. Hydrometeorol., 16, 2169-2186, doi:10.1175/JHM-D-140193.1, 2015.

Kliment, Z., Matouskova, M., Ledvinka, O., and Kralovec, V.: Trend Analysis of Rainfall-Runoff Regimes in Selected Head- 
water Areas of the Czech Republic, J. Hydrol. Hydromech., 59, 36-50, doi:10.2478/v10098-011-0003-y, 2011.

Knowles, N., Dettinger, M. D., and Cayan, D. R.: Trends in snowfall versus rainfall in theWestern United States, J. Climate, 19, 45454559, 2006.

Kucerova, D. and Jenicek, M.: Comparison of selected methods used for the calculation of the snowpack spatial distribution, Bystřice River basin, Czechia, Geografie, 119, 199-217, 2014.

Kutlakova, L. and Jenicek, M.: Modelling snow accumulation and snowmelt in the Bystrice River basin, Geografie, 117, 110-125, 2012.

Laghari, A. N., Vanham, D., and Rauch, W.: To what extent does climate change result in a shift in Alpine hydrology? A case study in the Austrian Alps, Hydrolog. Sci. J., 57, 103-117, doi:10.1080/02626667.2011.637040, 2012.

Langhammer, J., Su, Y., and Bernsteinová, J.: Runoff Response to Climate Warming and Forest Disturbance in a Mid-Mountain Basin, Water, 7, 3320-3342, doi:10.3390/w7073320, 2015.

Ledvinka, O.: Evolution of low flows in Czechia revisited, Proc. Int. Assoc. Hydrol. Sci., 369, 87-95, doi:10.5194/piahs-369-872015, 2015.

Lundquist, J. D. and Flint, A. L.: Onset of Snowmelt and Streamflow in 2004 in the Western United States: How Shading May Affect Spring Streamflow Timing in a Warmer World, J. Hydrometeorol., 7, 1199-1217, doi:10.1175/JHM539.1, 2006.

Pellicciotti, F., Bauder, A., and Parola, M.: Effect of glaciers on streamflow trends in the Swiss Alps, Water Resour. Res., 46, W10522, doi:10.1029/2009WR009039, 2010.

Pomeroy, J., Fang, X., and Ellis, C.: Sensitivity of snowmelt hydrology in Marmot Creek, Alberta, to forest cover disturbance, Hydrol. Process., 26, 1891-1904, doi:10.1002/hyp.9248, 2012.

R Core Team: R: A language and environment for statistical computing, R Foundation for Statistical Computing, Vienna, Austria, https://www.R-project.org/, last access: 28 June 2015.

Smakhtin, V. and Masse, B.: Continuous daily hydrograph simulation using duration curves of a precipitation index, Hydrol. Process., 14, 1083-1100, doi:10.1002/(SICI)10991085(20000430)14:6<1083::AID-HYP998>3.0.CO;2-2, 2000.

Speich, M. J. R., Bernhard, L., Teuling, A. J., and Zappa, M.: Application of bivariate mapping for hydrological classification and analysis of temporal change and scale effects in Switzerland, J. Hydrol., 523, 804-821, doi:10.1016/j.jhydrol.2015.01.086, 2015 .
Staudinger, M. and Seibert, J.: Predictability of low flow - An assessment with simulation experiments, J. Hydrol., 519, 13831393, doi:10.1016/j.jhydrol.2014.08.061, 2014.

Staudinger, M., Weiler, M., and Seibert, J.: Quantifying sensitivity to droughts - an experimental modeling approach, Hydrol. Earth Syst. Sci., 19, 1371-1384, doi:10.5194/hess-19-13712015, 2015.

Stewart, I. T., Cayan, D. R., and Dettinger, M. D.: Changes toward earlier streamflow timing across western North America, J. Climate, 18, 1136-1155, doi:10.1175/JCLI3321.1, 2005.

Tague, C. and Grant, G. E.: A geological framework for interpreting the low-flow regimes of Cascade streams, Willamette River Basin, Oregon, Water Resour. Res. 40, 1-9, doi:10.1029/2003WR002629, 2004.

Teuling, A. J., Van Loon, A. F., Seneviratne, S. I., Lehner, I., Aubinet, M., Heinesch, B., Bernhofer, C., Grünwald, T., Prasse, H., and Spank, U.: Evapotranspiration amplifies European summer drought, Geophys. Res. Lett., 40, 2071-2075, doi:10.1002/grl.50495, 2013.

Van Loon, A. F. and Laaha, G.: Hydrological drought severity explained by climate and catchment characteristics, J. Hydrol., 526, 3-14, doi:10.1016/j.jhydrol.2014.10.059, 2015.

Van Loon, A. F., Ploum, S. W., Parajka, J., Fleig, A. K., Garnier, E., Laaha, G., and Van Lanen, H. A. J.: Hydrological drought types in cold climates: quantitative analysis of causing factors and qualitative survey of impacts, Hydrol. Earth Syst. Sci., 19, 1993-2016, doi:10.5194/hess-19-1993-2015, 2015.

Viviroli, D., Zappa, M., Gurtz, J., and Weingartner, R.: An introduction to the hydrological modelling system PREVAH and its preand post-processing-tools, Environ. Model. Softw., 24, 12091222, doi:10.1016/j.envsoft.2009.04.001, 2009.

Whitaker, A. C., Sugiyama, H., and Hayakawa, K.: Effect of snow cover conditions on the hydrologic regime: Case study in a pluvial-nival watershed, Japan, J. Am. Water Resour. Assoc., 44, 814-828, doi:10.1111/j.1752-1688.2008.00206.x, 2008.

Zappa, M. and Kan, C.: Extreme heat and runoff extremes in the Swiss Alps, Nat. Hazards Earth Syst. Sci., 7, 375-389, doi:10.5194/nhess-7-375-2007, 2007.

Zhang, D., Cong, Z., Ni, G., Yang, D., and Hu, S.: Effects of snow ratio on annual runoff within the Budyko framework, Hydrol. Earth Syst. Sci., 19, 1977-1992, doi:10.5194/hess-19-19772015, 2015. 